\title{
Prejudicial Ruling on Addiction in Federal Immigration Courts: The Case of One Asylum Seeker Goes Before the $9^{\text {th }}$ Circuit Court
}

\author{
Reuben-Vaisman Tzachor* \\ California Licensed Psychologist, Counseling Center of Santa Monica, USA
}

*Corresponding author: Reuben-Vaisman Tzachor, California Licensed Psychologist 15091, Counseling Center of Santa Monica - A Psychological Corporation, 1731 Barry Avenue, \# 112, Los Angeles, California 90025, USA.

Received Date: April 28, 2020

Published Date: May 22, 2020

\begin{abstract}
The case of an asylum seeker who was the victim of prolonged torture and sex enslavement in her country of origin is pending before the $9^{\text {th }}$ Circuit Court of Appeals. This, after lower immigration authorities (i.e., Immigration Judge and Board of Immigration Appeals) refused to consider granting asylum because of "questionable moral character" of the applicant. The basis for the refusal were repeated Driving Under the Influence (DUI) offenses after the applicant developed an addiction to alcohol. The argument before the appellate court, and the argument of this article, is that addiction to alcohol was consequent to trauma sustained in the country of origin and that it is considered a mental disease, not an indication of immorality.
\end{abstract}

Keywords: Moral Character, Addiction, Trauma, Immigration, Asylum, Prejudice

\section{Introduction}

At the core of Federal Immigration Courts' consideration of applications for asylum in the U.S. is an impartial process which is meant to be free from prejudices. It follows that asylum seekers can expect their applications adjudicated by immigration authorities to be assessed against clear, objective, and predictable criteria. On the applicant's side, the claim for asylum would have to invoke protection from political or religious persecution; protection from exposure to criminal activity; protection from human trafficking; protection from persecution based on membership of a race or other ethnic membership; protection from persecution based on sexual orientation [1], and protection from other forms of persecution $[2,3]$. With the application for asylum there would be required evidence documenting the persecution, which is not often readily available to the applicant (because the persecution is often illicit, concealed, or both). In such situations, it is advisable to support the asylum application with a psychological evaluation that could produce probative evidence (usually in the form of documented
Post-Trauma Sequella directly related to persecution) when other documented evidence is lacking [4-7].

On the Federal Government side, asylum applications receive stringent review by adjudicators in the Department of Homeland Security and in the Department of Justice [8]. These involve rigorous background and security checks of the persons making the application and include also other relevant facts in each case. Additionally, asylum decisions are discretionary in the sense that the immigration judge or like authority, is tasked with weighing all evidence and other factors involved in the matter and decide entirely on the basis of their judgment. Some of the factors considered derive from current immigration law, which excludes persons who have committed criminal offenses, either in the U.S. or elsewhere; those who pose threats to national security; those who have committed "war crimes;" those who committed "crimes of moral turpitude" [9], and/or "crimes against humanity" [10-13]. 
For immigration judges adjudicating cases of asylum applications, the task to adhere to a consistent and coherent set of guidelines and protocols is made more difficult by the ever-changing landscape of immigration law. This, because of the many forms by which immigration policy is shaped and reshaped over-time, by the multitude of governmental agencies issuing sometime conflicting guidelines, and by failures of the legislative branch of government (i.e., congress) to update immigration law. Not surprisingly then, immigration law is fashioned no- less by judicial decrees from the bench, by Circuit Courts precedence-setting rulings, by executive branch regulations, as well as by the Supreme court decisions $[6,9]$.

The primary dilemma that asylum applications present to immigration authorities involve the question of veracity of the claims of persecution made by asylum applicants. This, because by and large, persons seeking asylum left their country of origin in a hurry, without sufficient or even adequate identification, let alone other materials that could support their claims of persecution [14]. Additional complication is that the majority of persecution cases are not documented and are in fact purposefully hidden from public view in other countries by the perpetrators themselves. This makes it virtually impossible for asylum applicants to obtain evidentiary material when such does not even exist and makes presenting their claims in immigration courts even harder [15-16].

An additional layer that frequently introduces more doubts for judicial officers involve the behaviors that asylum seekers engage in after they have taken shelter within the U.S. proper. This, because the majority of asylum seekers have been tortured and traumatized in their country of origin, leading up to their eventual escape. Thus, prior to coming to this country, most refuge seeking immigrants have already acquired in their country of origin a serious mental disorder; namely, Posttraumatic Stress Disorder [17]. This in turn, predisposes them to engage in a variety of compensatory behaviors in attempts to mitigate the emotional and psychological ravages that PTSD has had on them $[18,19]$.

The most common form by which persons who suffer from posttraumatic stress disorder obtain relief from their painful memories and other emotionally distressing experiences is with the use of substances [17]. Thus, commonly after their arrival to the U.S., and with the elimination of formerly extant threats upon them, many formerly tortured and persecuted immigrants develop an addiction secondary to their post-trauma syndrome. Hence, by the time they come to be considered for asylum in the U.S., many applicants have already garnered a few drug-related offenses (e.g., possession with intent to distribute, driving under the influence of a substance, disorderly conduct while intoxicated, etc.) on their criminal record [20].

The combination of circumstances common to many asylum applicants introduces an inherent bias against them in legal proceedings in the following manner: 1) Their application is adjudicated when they already have a criminal record in this country (making their claims more suspect); 2) They appear to be flaunting the law of the land in the country that sheltered them (thereby raising concerns regarding the authenticity and sincerity of their asylum claims); 3) They have inadequate documentation for their claims of persecution (which creates probative difficulty), and 4) The addiction to substances often masks the underlying psychological presentation of PTSD (even when a psychological evaluation in support of asylum claims is conducted).

Additionally, because of their proclivity to become haplessly re-victimized, asylum seekers often fall prey to criminal elements and to partner-abusive relationships within the U.S., where the traumatic pattern is repeated [14]. This pattern then makes the forensic distinction between the abuse suffered in the country of origin and the abuse suffered in the U.S. difficult to make, even by well-trained forensic experts [21]. Consequently, it is more difficult to determine which abuse claimed to have been suffered by the applicant, is actually responsible for the presentation of post-trauma sequella. Consequently, the determination whether the claim of persecution in the country of origin is legitimate or not becomes even harder to make $[2,7,13,22]$.

To illustrate this quandary, a case the author participated in as an expert forensic evaluator is offered as an example:

\section{The Case Before the $9^{\text {th }}$ Circuit Court of Appeals}

*Remark: The following account was obtained during a psychological evaluation and brief prepared for the Board of Immigration Appeals as part of a petition for a bond hearing. Consequently, personal and identifying details were changed or omitted to protect the privacy and safety of persons involved.

MRG was born in a small village in a Central American Country in 1971. In 1980, when she was nine (9) years-old her paternal grandfather who was an intelligence officer with the nation's military, was reportedly murdered by government agents. The murder was reportedly carried out because he was suspected by the military of acting as a "double agent" for the guerrillas. After the execution of her grandfather, MRG's father was arrested, and while in military custody, he was beaten to near-death for suspicion he too had been recruited by the anti- government guerrillas. This was also a common military tactic to "persuade" her father to act on behalf of the government and against the guerrillas from now on. Barely surviving his torture in captivity, and not wishing to repeat his ordeal of forcibly being recruited, MRG's father fled to the U.S. shortly after he was released by the government. Meanwhile, the word got out that the guerrillas were also trying to recruit able bodied persons of her village, so her two older brothers were moved out of the area to temporarily live with some distant relatives in the capital. This was done in order to protect them from forcibly being recruited by either side of the bloody civil war in her country.

As was expected however, members of the country's military soon arrived again in the village shortly after MRG's father and two 
brothers left. Their mission was to "prevent" the recruitment of the men into the guerrilla. When the military officials did not find any of the men at home, their suspicion grew that the men have been already recruited by the guerrillas and were now training in the jungles nearby. Consequently, the military repeatedly returned in subsequent years to MRG's family home at all hours, to see if they could surprise the missing men before they would vanish again. Whenever the women would be interrogated by military officers about the men's whereabouts, they would state that they did not know. They did so to protect themselves and their male family members as well. If the military would have found out that her father was in the U.S., they would have held the women of the family at ransom. This would force his return to the country, whereupon they would have all been killed. Meanwhile, and unbeknownst to the country's military, a few months after MRG's father escaped he sent for her brothers who were in hiding in the capital, and they too fled with help of a coyote to the U.S. and joined him in Los Angeles.

When MRG reached the age of fifteen (15) years-old, when she too could have been recruited into the guerrillas, the country's military officials' attention began to focus on her as well. In their visits to her home they would question her and suspect that she was an accomplice, because she persistently claimed not to know where her father was. The military therefore concluded that MRG's loyalty was already given to the guerrillas as well. So it was that in 1986, following one of those "investigative" visits, she was taken by the military into custody for suspicion of membership in the guerrillas. She later learned during her stay in custody that her incarceration was conceived with the intention to pressure her father to emerge out of hiding and give himself in to authorities.

She was held in captivity for a month or so, and during her imprisonment she was questioned repeatedly about the guerrillas and the whereabouts of her father and two brothers. The questioning was accompanied by all manner of torture, mainly administered by Mr. HSR, who most notably preferred to first beat her and then sexually assault and rape her. He reasoned that torturing MRG was his way of making her father "pay for his crimes" and the only way to force her father to surrender to him. All the while, her father never found out until much later what had happened to her and did not know of her arrest. She nonetheless has a permanent deformity of her jaws that precludes her from chewing without discomfort from apparent fractures that she sustained -- a souvenir from HSR punching her unconscious in one of her "interrogation" sessions. According to MRG, Mr. HSR seemed to enjoy sexually assaulting her, and impressed upon her that since he took her virginity, she was now "his woman" and that she was "not allowed" to be with anyone else. To ensure that she will tell no one and that she does not escape, HSR also placed some of his deputies ("comisionados") to monitor her every move while in the village. She was not allowed to leave to work or go to school and was to be available to him at home whenever he decided to show-up. She was essentially placed on "house-arrest" indefinitely.
Raised in a Catholic household and being of tender age she was easily convinced that Mr. HSR was right in his assertions that she now, according to the church's teachings "belonged to him." In addition, she was completely at his torturous mercy, to do with her as he pleased with absolute impunity. She therefore succumbed to his pressure and accepted the terms of her release: She was to be his punching-bag and sex-slave hereon out for him to enjoy as he pleased. She developed a typical "Stockholm Syndrome"* and passively accepted him as her man. She subsequently acquiesced to his demands and was therefore released from captivity back to her home in the village. Upon her return, she told nobody about what had happened to her as she was instructed to do. She kept her silence also for fear of being shamed by her family, and for fear of possibly being killed by guerrillas for having been "recruited" to the military's side. Mr. HSR thereafter would periodically pay her a "visit," in which he would take her away from the village for a few hours or a few days, beat her and rape her again, and then leave her to deal with the physical and emotional consequences on her own.

All told, and as a consequence of his raping her, MRG became pregnant with Mr. HSR five (5) times. The first pregnancy was conceived shortly after she was released from her detention when she was fifteen (15) years old. That pregnancy however resulted in a still-birth at five (5) months into her term because of the beatings she received from him while pregnant. The next pregnancy came shortly after the first abortion and this time Mr. HSR took her to a physician who injected her with a substance designed to induce an abortion. She nonetheless carried this pregnancy to term and gave birth to a malformed daughter when she was sixteen (16) years old. That girl barely survived to her first birthday before she succumbed to the legacy of her mother's torture and died. Sometime later MRG became pregnant again by Mr. HSR's rapes, and this pregnancy was also aborted at mid-term because of the beatings she sustained. The final two pregnancies bore two healthy boys and fortunately reached their term because HSR was apparently busy torturing and raping other women, giving her temporary relief. From his end, Mr. HSR took no interest in his offspring, one way or another. He would not so much as admit these were his children, until she tried to escape, when he kidnaped and held them at ransom to force her return.

MRG did not know at the time if Mr. HSR was married and whether he had other women in the region whom he also sexually enslaved for his pleasure, but she assumed she was not the only one. Most of all, she was terribly ashamed and did not want her boys to know the circumstances of their conception. She thus protected them the best way she knew how, by never telling them who their father truly was. When they would ask her about their father she would tell them that their father disappeared and would take the blame for him "leaving them," thus protecting the boys from feeling unloved and unwanted. When HSR would come to take her for another round of torture and rapes, she would leave her children with her mother and go with him away from the village. She was 
certain that Mr. HSR had informants in the area where she lived, which made her terrified of his potential punishment if she strayed. Since she did not want to cause him any reasons to retaliate against her, or possibly kill her, she had to be extra careful and tell nobody about her life. She never even told her mother anything even though she believes that her mother knew all along but pretended not to know to protect them all. MRG became exceedingly practiced at lying and obfuscating, to the point where sometimes she no longer knew what was true, and who she told what lie to.** All her efforts in those years concentrated on surviving and caring for her young boys, and protecting them from harm as best she could.

Ms. MRG had one confidant in the village named $\mathrm{R}$, who was an older woman that would come to fetch water from the well in the yard of MRG's family property. They became friends and R was the only person MRG told everything that was going on in her life to. With the help of her friend, the plot for her escape hatched between them, and MRG was readying to execute it. Soon thereafter however, HSR was told by his informants in the village of the friendship forming between the women and forbade it. To distract and "soften" him, MRG invited HSR for a "visit" and when he was done beating and raping her she prepared food for him, as if to insinuate that she accepted him as her "master and owner," and that she was not planning to leave. Thus, as soon as Mr. HSR left the village with his defenses down, R came to fetch water and secretly handed MRG money to facilitate her escape. That same night MRG left her children, five (5) years-old YO and three (3) years-old JE, in the care of her mother and ran away afoot onto the mountains and hid in the forest. She figured he would search for her in the jungles and leave her children alone, since he had no interest in them. Her plan was that while HSR was looking for her elsewhere, she would come out from hiding, go back to the village at night, and take her kids with her and escape with them for good.

She stayed in her hiding place in the woods and would move on the roads only in the darkness of the night, to avoid being seen or captured by HSR or his henchmen who were looking for her. She was so frightened and so worried for her children that she barely ate or drank water and reportedly lost considerable weight and most of her beautiful jet-black hair in those days. A few times during this waiting period she returned at night to see if she could take her children away with her, but R told her that HSR removed her kids from her mother's custody and placed them with "Seniora M" (who was the wife of the village commissioner and the chief collaborator with the military). Thus MRG begged Seniora M to let her "see" her children but she was refused because Seniora M was afraid that she too would be killed by her husband if he found out she disobeyed HSR's orders. On the eigth (8th) night however MRG got lucky and was able to kidnap her sons from the residence of Seniora M without being noticed. She immediately set afoot back onto the jungle while carrying the boys in her arms and on her back. After walking for about five (5) hours she arrived at a bus stop near dawn and took the bus north to the border with Mexico.
At the Mexico border she stayed with a woman who agreed to host her and the two boys for approximately one month. From there MRG communicated with her father in the U.S., who eventually sent her money to continue her journey. After the money arrived she paid her host and crossed into Chiapas in Mexico where she had to wait to be helped to cross through to the Mexico-U.S. border. She finally prevailed upon another coyote to help pass her through, but since she was running out of money she shamefully had to offer her sex in exchange for his services. Thankfully for her, this sexual encounter with the coyote did not produce another pregnancy. Ms. MRG and her sons eventually arrived to the "Las Virgins" ranch house in the area of "Salvaterra" near the U.S.-Mexico border, where they waited for approximately two months. The ranch clearly belonged to human and drug traffickers who waited for the opportune moment and eventually helped her cross into the U.S. She finally arrived to Los Angeles and joined her father and brothers some time in 1994.

As many asylum seekers do, she felt very confused and exceptionally anxious in the first months of her arrival in the U.S. She was generously helped however by family members and members of a Catholic church where other refugees of her country worshiped. She soon found work as a housemaid for a wealthy Beverly Hills family and continued to financially support herself and her family ever since. Sometime after her arrival in the U.S., she was encouraged by her father and brothers to file an application for asylum and withholding of removal to INS pursuant to legal provisions of that time. She went with her father and brother to an office of a notary public who filled out a form on her behalf, had her sign it, and submitted on her behalf the application. She remembers mostly signing where she was told to sign, but she was unsure how well the documentation represented the complexity of her situation.

In 1995, she obtained an interview with immigration officials pursuant to her application for asylum. She was interrogated by an immigration officer who was dressed in uniform that terrified her because it was the same shade of green that Mr. HSR wore. She remembers that the interview "did not go well" because the interviewer could not speak Spanish, the interpreter did not understand what she was saying, and she became often flustered. She could not quite explain the intricacies of her circumstances to the officer and was unsure how much she should reveal about herself. In the interview she was pointedly asked why she was afraid to return to her country of origin, but since she did not want to entrust with the truth someone wearing the same kind of uniform as her torturer, she did not adequately explained herself.

Convinced that the violence in his country has subsided and hoping to return to his life in his homeland, her father returned back home in 1997. He settled in the area they all hailed from but did not return to live with her mother because they were no longer on speaking terms after years of separation. He subsequently reportedly settled in the town of L.A. near the village she grew up in, trying to regain what was once his life. There he resumed his work as a farmer and wanted to live out his days in peace and within his 
modest means. In the years after his return, her father periodically communicated with MRG via telephone and told her that he was repeatedly visited by Mr. HSR, who was now in the national police force. Her father indicated that Mr. HSR asked about her and "his sons" and that he was told that MRG was living in the U.S., to which the policeman would react with visible anger. Apparently threatening her father Mr. HSR wanted to pressure MRG's father to persuade her to return to the country, but her father would promise HSR that he will "never in his life" see MRG again.

The threatening nature of the news that came to her from her country via telephone conversations with her father terrified her. She realized that her torturer was still lurking around, looking for her and she became increasingly afraid. She began to relive the memories of sexual abuse and torture that she endured at the hands of Mr. HSR and she became extremely "stressed" and paranoid. Crying she admits that she subsequently began to drink alcohol to drown the memories and the emotional pain she was re-experiencing on a regular basis. Her drinking gradually and progressively got out of control because she was not able to quiet down the thoughts, memories, and fears unless she was drunk.

In her emotional upheaval and rage she vacillated between the impulse to return to her country and re-submit herself to HSR to save her father, or the equally powerful desire to escape any which way possible. As a matter of fact, her brothers had to stop her enroute to the airport because she was getting ready to fly back to her country of origin more than once. In her desperate need to find expression for her anger and emotional support she befriended female gang members and entertained the idea of joining their gang. She subsequently used drugs with the gangsters and on her own, in complete reckless abandon. Subsequently, in 2001, she was arrested and convicted for driving under the influence (DUI) of alcohol. She was sentenced to a program for alcohol and drugs rehabilitation, which she subsequently successfully completed. In retrospect she realized that the program helped her sustain a temporary sober lifestyle but did nothing to help her overcome the traumas she suffered, and which gave rise to her alcohol drinking in the first place.

At about the time she became alcohol-free she was working as a waitress at a restaurant in Los Angeles where Mr. GR, a Mexican national frequented as a customer. They began dating in 2001 and eventually consummated their relationship. For a while, MRG felt that she could turn her life around and maintain her sobriety with the loving support of her man. GR was kind and patient with her typical aversion to physical and sexual contact with him and other PTSD manifestations MRG displayed. He even recommended she seek psychological help for her emotional problems but she would protest that she was "not crazy" and refused to find assistance. In retrospect MRG realizes that his advice was well intended and probably something she should have heeded. At that time however, she admits she was young, naive, and rather misguided about what was happening to her.
In 2002, Ms. MRG received a phone call from a friend of the family from her country named 0 , who informed her that her father was murdered and that the prime-suspect is Mr. HSR. O further explained the circumstances that lead to this conclusion, since her father was seen followed by police and his body was found by the side of the road close to where he was last seen being followed by Mr. HSR. The family friend also informed MRG that HSR will never be prosecuted for the murder because he is "immune" since he continues to work for the police department in the area. She was also told that Mr. HSR continues to ask around about her and looks for ways to pressure her to return from the U.S. to him. Ms. MRG was terrified and concluded that she can never return to her country of origin if she wants to live free from "this horrible monster of a man." She soon thereafter started using drugs and alcohol again to quiet her fears, periodically planning to return to her country to confront HSR, and at other times contemplating re-joining a gang once more.

In subsequent years MRG and GR had their daughter, E (now fourteen [14] years-old) who was born in Los Angeles in 2006, thereby making her a US-born citizen. During the eight (8) years tenure of her relationship with Mr. GR, Ms. MRG suffered many of the symptoms of PTSD, activated primarily by her spouse's desire to have sex with her and her subsequent pregnancy. Much of her intimate encounters with Mr. GR reminded her of the sexual assaults and rapes by Mr. HSR, and the pregnancy with her daughter also reminded her of previous unwanted and unwelcome pregnancies with Mr. HSR. Upon the birth of her daughter Ms. MRG slipped into postpartum depression and lacking the psychological skills or resources to overcome her reawakened trauma, she began to drink alcohol once more. Her spouse was well-meaning but ill-equipped to handle what she was going through, and the relationship between them deteriorated over time. E was raised by both GR and she until their daughter was seven (7) years- old when in 2013, in a moment of frustration RG beat her up and she called police for domestic violence. Mr. GR was subsequently arrested and later asked Ms. MRG and was granted reunification with his family. That reunification effort however did not last, as some time later Mr. GR cheated with another woman, whereupon the relationship finally and acrimoniously ended.

All the distress surrounding the intimate relationship with Mr. GR; the pregnancy and birth of her daughter; subsequent postpartum depression, and subsequent stress of parenting a young child came at a very high price. Ms. MRG resumed her alcohol drinking and in 2013 was arrested a second (2nd) time for driving under the influence of alcohol (DUI). She was subsequently convicted and sentenced to attend Alcoholics Anonymous (AA) meetings, to visit a morgue and to visit a hospital for persons injured by vehicular accidents caused by drivers under the influence of alcohol or drugs. She once more completed her sentence and vowed never to drink alcohol again, but in retrospect realized that the sources of her distress were never addressed, and it was only a matter of time before the 
disturbing memories of her past and the images of her torture invading her consciousness haunted her once more. And so they did.

In 2011 she met her current boyfriend, Mr. SC who was at the time an auto-shop mechanic in the facility she was servicing her vehicle at. By the time her relationship with Mr. GR was dwindling to an end in 2014, she was now forty four (44) years-old. She began to feel guilty for the demise of the relationship and ashamed of herself for reacting in the ways in which she did to him. She could not bear to engage sexually with her man, and she was becoming depressed during and after her only pregnancy with him. She began questioning her value as a woman and as a spouse and feeling like "damaged goods" she became depressed again.

Additionally, she was removed from her residence with Mr. GR during the separation, so she had nowhere to live. Ms. MRG subsequently sought shelter in the arms and home of Mr. SC and begrudgingly became his woman since then. All the while she still felt like a hostage who is controlled by any man she lives with because of her past. She subsequently spiraled psychologically once more, while going through the motions, and while continuing to put on her best face forward. All the masquerading of her true distress did nothing to produce relief, and she resumed alcohol drinking once again. Subsequently, she was arrested for the third (3rd) time in 2017 for driving under the influence (DUI) of alcohol and for causing bodily harm in a vehicular accident she was involved in. Ms. MRG was subsequently transferred to ICE detention in Adelanto, California pending deportation, and where she continued to reside at the time of this evaluation.

*Stockholm Syndrome or capture-bonding is a well-known phenomenon where hostages develop empathy, sympathy, and positive feelings toward their captors, sometimes to the point of defending and identifying with their captors. This effect is enhanced the greater the control exerted by the captors upon the hostage.

**Secrets and Lies, when practiced for long periods of time by victims of torture can have the effect of confusing the person making the lies, and can form "False Memories" that often lead a person to question their own facts and memories thereafter.

\section{Excerpts from Legal Decisions by Immigration Judges in This Case}

The statutory eligibility for cancellation of removal requires a respondent, among other things to show that she has been a person of good moral character for ten years, calculated backward from the date on which the application is finally resolved by an Immigration Judge [23]. Moreover, a respondent cannot have been convicted of a crime involving moral turpitude, which would have rendered any alien inadmissible by statute [9]. The court noted that the respondent has been convicted of two (2) DUIs in violation of CVC 23152, as well as one (1) count of driving under the influence and causing bodily injury in violation of CVC 23153. It held however that these convictions are not within the listed classes of ineligible aliens un- der Immigration and Naturalization Act (INA) 101(f) and are not convictions directly barring Ms. MRG from eligibility [24]. Thus, these criminal convictions did not mandatorily disqualify the respondent from the relief she was seeking at the time.

As indicated before, the Court holds discretionary authority above and beyond statutory eligibility, which means that even if an applicant demonstrated statutory eligibility for cancellation of removal, the applicant bears the burden of showing that relief is warranted in the exercise of the court's discretion [25]. In other words, even when the respondent's statutory eligibility is undisputed, the decision to grant relief is a "matter of grace, not right" [26]. Thus, to determine whether to exercise discretion the Court considers among other, adverse factors such as entering the United States under fraudulent circumstances or committing crimes while in the United States.

In the decision in this case, the Immigration Judge expressed "concern by the nature, recency, and consistency of the respondent's criminal convictions." It further emphasized the Supreme Court of the United States ruling [27] indicating "drunk driving is an extremely dangerous crime." and cited also:

"The dangers of drunk driving are well-known and well-documented. Unlike other acts that may present some risk of physical injury... the risk of injury from drunk driving is neither conjectural nor speculative. Driving under the influence vastly increases the probability that the driver will injure someone in an accident." [28]. Thus, the Court denied the respondent's application for cancellation of removal as a matter of discretion as well, noting her criminal record and lack of due diligence and failure to rehabilitate from her crimes [29]. Hence, Immigration Court considered Ms. MRG's DUI convictions and subsequent failures to rehabilitate as rendering her of "questionable moral character" and therefore not eligible for relief.

In attempting to make a "threshold determination of MRG's credibility" when considering whether she meets the statutory criteria for asylum [30], the Court also considered MRG's testimony taken by immigration officials first, without corroboration. Her testimony could have been potentially sufficient to meet the burden of proof if her asylum application was believable, consistent, and sufficiently detailed to provide a "plausible and coherent account of the basis of relief" [31]. Credibility determinations require the Immigration Court to look at the "totality of the circumstances and all relevant factors" [32], including both consistencies and inconsistencies, omissions, implausibilities, and corroboration in the respondent's claim. The Court further recognized that mere omission of details is insufficient to uphold an adverse credibility finding [33] but found that omissions critical to Ms. MRG's claim of asylum were found in the testimony she gave immigration authorities. Thus, the Immigration Judge found that material alterations in Ms. MRG's account of persecution were sufficient to support an adverse credi- 
bility finding as held by the 9th Circuit Court of Appeals [34,35] in this matter, because the omissions "went to the core of MRG's fear of political persecution."

The omissions, inconsistencies, and implausibilities in the testimony obtained from Ms. MRG, which went to the ultimate adverse credibility finding seem to have emerged from a rather misguided "presumption of regularity" by immigration officers [36,37]. The presumption of regularity in Federal Immigration Laws "supports the official acts of public officers, and in the absence of clear evidence to the contrary, courts presume that they have properly discharged their official duties" (in this case, "properly discharged duties" would entail obtaining accurate and reliable testimony from MRG). As could be noted from the psychological evaluation and account of events detailed above, it was not that the immigration officer did not attempt to discharge his official duties fairly or accurately, rather it was that the immigration official was unable to do so. This, because the official who interviewed Ms. MRG was not trained and therefore unskilled at interviewing a person who suffers from severe mental illness (i.e., Posttraumatic Stress Disorder and Alcohol Use Disorder).

Consequently, the inaccuracies, inconsistencies, omissions, and implausibilities were all haplessly introduced into the record by the interviewer, who could not separate the relevant and true information from the "noise" that MRG's psychological defenses and psychiatric illness produced $[13,21,22]$. Additionally, the immigration officer who took Ms. MRG's testimony was unable to understand her because he could not speak Spanish, and had to rely on the translation of another person, thereby introducing more inaccuracies into the record $[21,38]$. Finally, the immigration officer was not aware of, and could not have been aware of all the barriers to effective communication and accurate interviewing he was facing, without adequate training in cross-cultural communication [21,39]. It has been therefore the standing recommendation that all immigration applications, and particularly all asylum applications be accompanied by a psychological evaluation, to increase accuracy, validity, and reliability of the information presented to the Court for consideration [7,41-43].

\section{Alcohol Addiction}

The Diagnostic and Statistical Manual of Mental Disorders Fifth Edition (DSM-5) categorizes Alcohol-Related Disorders in the Substance-Related and Addictive Disorders category. It identifies 10 classes of drugs (including alcohol) that are taken in excess, and have in common the direct activation of the brain reward system, which is involved in the reinforcement of behaviors and production of memories. Furthermore, individuals with lower levels of self-control to begin with, and victims of trauma are particularly predisposed to develop substance use disorders. Alcohol use disorder is further defined as a "problematic pattern of alcohol use leading to clinically significant impairment or distress" [17].
Among the DSM-5 diagnostic criteria that seem to fit the respondent in this case, are " 6 . Continued alcohol use despite having persistent or recurrent social or interpersonal problems caused or exacerbated by the effects of alcohol; 8. Recurrent alcohol use in situations in which it is physically hazardous, and 9. Alcohol use is continued despite knowledge of having a persistent or recurrent physical or psychological problem that is likely to have been caused or exacerbated by alcohol" [17]. As such Ms. MRG meets the criteria to be formally diagnosed as suffering from an Alcohol Use Disorder.

The typical course of Alcohol Use Disorder is characterized in the DSM- 5 by periods of remission and relapse. A decision to stop drinking, often in response to a crisis (such as a DUI), is likely to be followed by a period of weeks or more of abstinence, which is often followed by limited periods of controlled or non-problematic drinking. However, once alcohol intake resumes, it is highly likely that consumption will rapidly escalate and that severe problems will once again develop [17].

The DSM-5 further notes that "Alcohol Use Disorder is often erroneously perceived as an intractable condition, perhaps based on the fact that individuals who present for treatment typically have a history of many years of severe alcohol-related problems. However, these most severe cases represent only a small proportion of individuals with this disorder, and the typical individual with the disorder has a much more promising prognosis" [17].

As can be determined by the above analysis, Ms. MRG is not irreparably morally flawed in her character, as the Immigration Judge (IJ) concluded. Rather, she suffers from a common mental condition which is well known to the medical and psychological community, and which has known treatments for. The fact of the matter is that Ms. MRG suffers from Alcohol Use Disorder which has developed subsequent to her Post Traumatic Stress Disorder, which is a fairly common pattern for this condition.

Additionally, while Ms. MRG has been ordered in the past and completed alcohol treatment and AA courses, they are in and of themselves not a guarantee for ultimate success or eternal abstinence. Current advances in psychiatric medicinal treatments (such as Anti- Depressant and Anti-Seizure medicines frequently prescribed to addicts) and other rehabilitative treatment measures could prove more effective in sustaining her long-term abstinence. Her bond release or asylum application could have easily been predicated upon indefinite maintenance of sober lifestyle combined with mandated psychological and psychiatric treatment designed to reduce the chances of recidivism.

\section{The Psychology of Morality}

The Diagnostic and Statistical Manual of Mental Disorders, Fifth Edition (DSM-5) identifies a particular cluster of behaviors and attitudes of the Antisocial Personality Disorder as consistent with what is commonly known as psychopathy, or lack of moral character. The Diagnostic Criteria required to reach the diagnostic thresh- 
old involves a "pervasive pattern of disregard for and violation of the rights of others, occurring since age 15 , as indicated by three or more of the following: 1. Failure to conform to social norms with respect to lawful behaviors, as indicated by repeatedly performing acts that are grounds for arrest.; 2. Deceitfulness, as indicated by repeated lying, use of aliases, or conning others for personal profit or pleasure.; 3. Impulsivity or failure to plan ahead.; 4. Irritability and aggressiveness, as indicated by repeated physical fights or assaults.; 5. Reckless disregard for safety of self or others.; 6. Consistent irresponsibility, as indicated by repeated failure to sustain consistent work behavior or honor financial obligations., and 7. Lack of remorse, as indicated by being indifferent to or rationalizing having hurt, mistreated, or stolen from another." [17].

As can be determined from this definition, Ms. MRG does not fit this diagnostic category, and therefore could not be considered of questionable moral character. In fact, Ms. MRG demonstrated exceptional moral fortitude when acting throughout her life with the concerns and interests of others (e.g., family members, her children, etc.) in mind over her own. In any event, the defendant in this case does not fit the psychological profile of and Antisocial Personality Disordered individual, and therefore cannot be considered from a psychiatric or psychological stand point to be of questionable moral character.

\section{Post Traumatic Stress Disorder and Shame}

The Diagnostic and Statistical Manual of Mental Disorders, Fifth Edition (DSM-5) identifies Post Traumatic Stress Disorder in the category of Trauma and Stressor-Related disorders group. Disorders in this group include disorders in which exposure to traumatic or stressful event (such as sexual abuse while imprisoned) is listed explicitly as a diagnostic criterion. The respondent specifically meets Posttraumatic Stress Disorder diagnostic criteria in the following manner: "A. Exposure to actual or threatened death, serious injury, or sexual violence in one or more of the following; 1 . Directly experiencing the traumatic events" [17]. Ms. MRG reported having been sexually assaulted and raped numerous times during her adolescence and early adulthood.

She additionally meets the other diagnostic criteria of: "B. Presence of one or more of the following intrusion symptoms associated with the traumatic events...; 1 . Recurrent, involuntary, and intrusive distressing memories of the traumatic events."; and "C. Persistent avoidance of stimuli associated with the traumatic events...; 2 . Avoidance of or efforts to avoid external reminders (people, places, conversations, activities, objects, situations) that arouse distressing memories, thoughts, or feelings about or closely associated with the traumatic events."; and “D. Negative alterations in cognition and mood associated with the traumatic events...; 4. Persistent negative emotional state (e.g., fear, horror, anger, guilt, or shame)." and "E. Marked alterations in arousal and reactivity associated with the traumatic event...; 2. Reckless or self-destructive behavior" [17].

Persons who suffer Posttraumatic Stress Disorder show the greatest representation in drug and alcohol rehabilitation pro- grams ( $80 \%$ by some estimates). This, because it is most frequent that persons suffering from this condition medicate their psychological pain with the use of drugs or alcohol. Additionally, persons who were held hostages and/or tortured often tend to develop passive and dependent characteristic behaviors, and subsequently identify with their tormentors. Most importantly in this case, persons suffering from this condition also tend to feel guilty for what happened to them and shame for having succumbed to the torture and maltreatment. Consequently, they are loath to disclose and discuss the nature of their experiences and often lie and deny their past in a furtive attempt to make it "disappear" [17].

The evidence from Ms. MRG's evaluation is conclusive with regards to the diagnosis of Posttraumatic Stress Disorder. She has suffered significant physical and sexual trauma, allegedly in the hands of her torturer and rapist, Mr. HSR. She was incarcerated and sexually assaulted in her home country first when she was fifteen (15) years-old and the rape, intimidation and assault continued thereafter. She had multiple unwanted pregnancies by her assailant for which she primarily blamed herself and felt immensely ashamed off. She nonetheless proceeded to raise his sons while sheltering them from the awful truth about the circumstances of their conceptions. She remains afraid of ongoing persecution and continues to exhibit all PTSD sequella of fear, apprehension, anxiety, depression, intrusive experiences, avoidance behaviors, and persistent guilt and shame.

\section{Conclusion}

The case of Ms. MRG represents a tendency of the legal community and particularly of the Immigration Control and Enforcement (ICE) apparatus to hold prejudicial views about substance use disorders as largely reflecting upon the moral character of addicted applicants. As such, persons who are adjudicated in substance-related offenses tend to be considered of "questionable moral character" and their asylum applications tend to be largely rejected on that basis. The case-law upon which these judicial decisions are rendered is not only inconsistent with commonplace understanding of distinctions between morality and immorality; but also flies in the face of scientific knowledge, and contrary to commonplace medical, psychiatric, and psychological practice. As such, these decisions are rendered in direct contradiction with the 1923 Frye Test of evidence as detailed in Federal Rules of Evidence [4,13], and could be therefore invalid or rendered unconstitutional.

Additionally, the case of Ms. MRG clearly indicates upon the flawed process by which information is obtained by immigration authorities in order to consider the merits of an asylum case. This, because evidence is obtained by immigration officers that interview respondents, who by and large, are afflicted by mental disorders (most notably Posttraumatic Stress Disorder and often secondary Substance Use Disorder). Since immigration officials are not trained mental health professionals, nor are they forensic psychology experts, the evidentiary material they manage to collect is both of questionable accuracy, and gravely contaminated by 
the pathological processes they evoke in their interviewees. Consequently, the decisions rendered by immigration judges are largely based on erroneous information and questionable evidence, leading to unfortunate gross miscarriage of justice.

\section{Acknowledgement}

None.

\section{Conflict of Interest}

Author declare no conflict of interest.

\section{References}

1. Amnesty International (2003) Death by discrimination. The continuing role of race in capital cases.

2. Rempell S (2009) Defining persecution.

3. (2010) Federal Rules Book. American Bar Association Publishing, Chicago, USA.

4. Buckles T (2003) Laws of evidence. Delmar Learning Publishing, NY, USA.

5. Vaisman-Tzachor R (2003) Psychological assessment protocol in Federal immigration courts. The Forensic Examiner 12(3\&4): 34-40.

6. Vaisman-Tzachor R (2012) Psychological evaluations in Federal immigration courts: Fifteen years in the making - lessons learned. The Forensic Examiner 21(2): 42-53.

7. Vaisman-Tzachor R (2019) Psychological assessment protocol for asylum applications in Federal Immigration Courts. Journal of the American Academy of Experts in Traumatic Stress 1(1): 16-27.

8. US Congress (2002) The Homeland Security Act. Public License Number 107-296, 116 Stat. 2135.

9. Yardum-Hunter A (2011) Misuse of Social Security number considered a "Crime Involving Moral Turpitude," Eighth Circuit rules. Yardum-Hunter Immigration Status Newsletter 6 (1): 6-7.

10. Hing OB (2004) Defining America through immigration policy. Temple University Press, Philadelphia, USA.

11. American Bar Association (2010). Immigration Court Practice Manual.

12. Schaefer K (2012) Asylum in the United States.

13. Weiner IB, Hess AK (2006) The handbook of forensic psychology. ( $3^{\text {rd }}$ edn). John Wiley \& Sons, New York, USA.

14. Casey ES, Watkins M (2014) Up Against the Wall. University of Texas Press, TX, USA.

15. McBride MJ (1999) The evolution of U.S. immigration and refugee policy: Public opinion, domestic politics and UNHCR. New Issues in Refugee Research, May.

16. Office of the Federal Register (2010) Code of federal regulations aliens and nationality. Government Printing Office, Washington, USA.

17. American Psychiatric Association (2013) Diagnostic and Statistical Manual of Mental Disorders. ( $5^{\text {th }}$ edn). American Psychiatric Publishing, Washington DC, USA.
18. Frumkin I, Friedland J (1995) Forensic evaluations in immigration cases: Evolving issues. Behavioral Sciences and the Law, 13(4): 477-489.

19. Cervantes JM, Mejia OL, Mena A (2010) Serial migration and the assessment of extreme and unusual psychological hardship with undocumented Latina/o families. Hispanic Journal of Behavioral Sciences 32 (2): 275-291.

20. Frelick B (2005) US detention of asylum seekers and human rights. Amnesty International USA. Migration Information Source.

21. Paniagua FA (2016) Assessing and Treating Culturally Diverse Clients. ( $4^{\text {th }}$ edn). Sage Publications, CA, USA.

22. Aranda R (2016) Living in the shadows: Plight of the undocumented. J Clin Psychol 72(8): 795-806.

23. Board of Immigration Appeals (2005) Matter of Ortega-Cabrera, 23 I\&N Dec 793.

24. Board of Immigration Appeals (1999). Matter of Lopez-Meza, 22 I\&N Dec. 1188, 1194.

25. Board of Immigration Appeals (1998). Matter of O-D, 21 I\&N Dec. 1079, 1081.

26. Elkins vs Moreno (1978) Matter of Elkins v Moreno. 435 US, 647-667.

27. Begay Vs United States (2008) Matter of Begay vs United States. 553 US. 137, pp. 141-42.

28. United States vs Rutherford (1995) Matter of United States vs Rutherford. 370-376.

29. M-R-G vs United States (2018) Matter of M-R-G vs United States 25-27.

30. Board of Immigration Appeals (1998) Matter of C-V-T, 22 I\&N Dec 7, 8-10.

31. Board of Immigration Appeals (2007) Matter of J-Y-C, 24 I\&N Dec. 260262.

32. $9^{\text {th }}$ Circuit Court of Appeals (2010) Shrestha v Holder, 590 F .3d 10341040.

33. $9^{\text {th }}$ Circuit Court of Appeals (2014) Lai v Holder, 773 F. 3d 966-971.

34. $9^{\text {th }}$ Circuit Court of Appeals (2011) Zamanov v Holder, 649 F. 3d 969.

35. $9^{\text {th }}$ Circuit Court of Appeals (2016) Silva-Pereira v Lynch, 827 F. 3d 1176, 1185-86.

36. $9^{\text {th }}$ Circuit Court of Appeals (2016) Kohli v Gonzalez, 473 F. 3d 10611068.

37. United States vs Chemical (1926) Matter of United States vs Chemical Foundation. 272 US 1: 14-15.

38. Rosenblum KE, Travis TM (2015) The Meaning of Difference. ( $7^{\text {th }}$ edn). McGraw Hill Higher Education, Boston, USA.

39. Vaisman-Tzachor R (2018) A terrorism prevention imperative: Psychological evaluations for all immigrants. Journal of Police Emergency Response 18(2): 1-11.

40. Vaisman-Tzachor R (2017) Psychological evaluations for immigration also for terrorism prevention. Psychology and Behavioral Science International Journal 3(2).

41. $9^{\text {th }}$ Circuit Court of Appeals (2009) Marmolejo Campos v Holder, 558 F. 3d 903-913. 